\title{
Andrew McGahan's Wonders of a Godless World: A Transparent Space of Darkness
}

Salhia Ben-Messahel

\section{(2) OpenEdition \\ 1 Journals}

Electronic version

URL: https://journals.openedition.org/ces/5443

DOI: $10.4000 /$ ces.5443

ISSN: 2534-6695

Publisher

SEPC (Société d'études des pays du Commonwealth)

\section{Printed version}

Date of publication: 1 September 2012

Number of pages: 93-102

ISSN: 2270-0633

\section{Electronic reference}

Salhia Ben-Messahel, "Andrew McGahan's Wonders of a Godless World: A Transparent Space of Darkness ", Commonwealth Essays and Studies [Online], 35.1 | 2012, Online since 18 April 2021, connection on 23 July 2021. URL: http://journals.openedition.org/ces/5443 ; DOI: https://doi.org/ $10.4000 /$ ces. 5443

\section{cc)}

Commonwealth Essays and Studies is licensed under a Licence Creative Commons Attribution - Pas d'Utilisation Commerciale - Pas de Modification 4.0 International. 


\section{Andrew McGahan's Wonders of a Godless World: A Transparent Space of Darkness}

Andrew McGahan's Wonders of a Godless World (2009) explores consciousness, reality and madness through the main viewpoints of two odd and mysterious characters. Set in a psychiatric ward reminiscent of Bentham's panopticon, the story is an eye-opening journey into a transparent society characterized by the singular connections it makes between the visible and the invisible. Dreams and fantasy delineate spaces of otherness that call forth questions of perspective and reliability. The multi-layered narrative combines strategies of invisibility with the staging of the self so that while transparency normally implies openness, communication, and accountability, it can also operate in such a way that it becomes difficult to ascertain the characters' actions.

Since his very first and much celebrated novel Praise, a semi-autobiographical account of a doomed, drug- and alcohol-fuelled relationship in the state of Queensland, Andrew McGahan's writing has been preoccupied with social, cultural and political issues from the last phase of the twentieth century onwards, to suggest that Australia is no longer the egalitarian society and land of plenty securing the principle of fair-go and opportunities that illustrated the formation of the nation since the beginning of colonization. McGahan's novel The White Earth tackled land rights and ownership at a particular moment in Australian history, when the government was clearly refusing to address the issue of land rights and reconciliation with the indigenous past. Underground extended the novelist's critical response to the neo-conservative discourse of the Federal Government, weaving an absurdist satire to criticize the more extreme manifestations of the War on Terror in Australia. In this novel, McGahan interrogates the tenets of multiculturalism in postcolonial Australia, wondering about the incorporation of Australia's indigenous population and migrant others within the country's multicultural framework.

Wonders of a Godless World focuses on the notions of land as a territory of meaning and as a process of transformation. Such a concern prevalently rests upon the interplay of diaphaneity and opacity, translucency and haziness. The story ironically relates to the importance of a spiritual environment throughout various stages of humanity, the amazing things the natural world has designed without man or the Holy Spirit, and thus oscillates between the obvious and the unsaid, precision and ambiguity, prompting questions of viewpoint and reliability. Fantasy operates as a natural and rational means of expression so that images allow perception to pass through and so that objects behind, like the earth, can be distinctly seen. The novel focuses on environmental issues and the centrality of the land in people's lives to explore consciousness and madness, suggesting that human beings are alienated from the soul of the earth and that one's experience of the world swings between extremes, a commitment to the spiritual environment and the desire to exploit natural riches for capitalistic purposes and the idea of progress. Set in a gothic hospital - with the psychiatric ward in lieu of a castle - sitting in the shadow of a volcano on an unnamed tropical island, the story develops as a fable about human intervention on geology and the weather, human folly, immortality and madness. It starts in medias res with the ordinary perception of the main female character 
known as "the orphan" and the arrival of a new patient known as "the foreigner." As soon as the patient is able to communicate with the orphan, speaking to her from his comatose state, a bizarre relationship develops between both that involves out-of-body journeys through time and space:

One part of the orphan could feel that she was still sitting by the bedside, and that her fingers were still clasped around the foreigner's passive hand. But another part of her felt cut loose. Weightless. Floating. A shadow self. And the shadow self was being pulled forward by a hand far more compelling. The foreigner was leading her on, a shadow too it seemed, a ghost form with no more substance than mist - but in control of her. (66)

Thanks to the foreigner, the orphan is able to discover "the wonders of a godless world," a transparent world where the natural environment takes precedence over man and where she can fully connect with her other self. She is able to look at the centre of her soul from the earth and the surrounding elements, just like the foreigner. The environment is clearly posited as a substratum for both the outside reality and the imaginative world of the two main characters, encapsulating spaces of otherness, which are neither here nor there and that can be simultaneously physical and mental. The development of the story triggers a multiplicity of viewpoints which render representations of the world and society more complex and chaotic and which seem to rely on magic realism. Indeed, in the context of postcolonial writing, the use of magic realism points to the inherent problems created by the imposition of a bizarre and unreal Western world-view onto the local reality of the other; it is the way of approaching truth by other means, by combining mutually exclusive thought systems. ${ }^{1}$ Yet, while $W$ onders of a Godless World seems to suggest some of these ideas, it also clearly verges on fantasy as a liminal space to examine historical, political and social events that take place in reality. From the opening pages of the novel, McGahan uses elements found in myth or fairy tales, such as demons, royal figures, witches, angels and a virgin girl, displacing the main story and sub-stories to far-away, distant and unknown places that recall the position of Australia as an island on the periphery of other centres (68-9).

The arrival of the new male patient, the foreigner, is illustrated by a growing expectation and sense of omen discernable through unstable weather conditions and strange, telluric manifestations. The character's presence seems to partake of the movements of the earth, especially with an erupting earthquake that seems to interact with the orphan's own sexual pleasure:

Her own madness was alive too. She could feel beneath her feet, trembling and quivering. It was as if, far below in the earth, a giant machine hummed. The vibrations buzzed against her heels, running right up between her legs, and she couldn't decide if it felt bad or if she was on the edge of an orgasm where she stood. But something was about to happen, she was sure. And by chance she was out the front - emptying her mop bucket in the drainage ditch - when the arrival took place. (2)

The throbbing environment mysteriously liberates the character from the constraints of her "retarded reason" in a flow of emotions sustained by divergent forces and elements. Place functions as heterotopia in the Foucauldian sense (46-9) so that it creates both a space of illusion and a real space - a space that is other. The ordinary life and daily

1. "Magic Realism" has several possible definitions and is understood, in the novel, as the genre combining reality and surreality on the same plane. It is a way of raising the world's political, economic and social problems by attempting to reach out to a lost and glorified past. 
boredom of the orphan are disrupted by the eerie presence of the comatose foreigner, whose identity and origin remain mysterious: he does not seem to belong anywhere; he is neither a local nor a tourist and does not seem to be related to any living soul on earth. Despite his apparent unconsciousness, the foreigner provides the catalyst for most of the action. He is almost like a God to the orphan, speaking directly to her from his coma, a translucent space beyond reality, a space where strange phenomena occur and where the orphan can evolve from being a speechless, inanimate, sexless ugly duckling to an active and attractive "goddess of fertility" (259).

Both characters voyage through physical and mental spaces to examine the world, its peoples and cultures. The foreigner embodies the encounter of the real and the unreal in that he claims he is cursed with immortality, being more than a century old and recounting five deaths, each followed by a painful rebirth. He is intimately acquainted with the blind forces that bind together dual matters: rock and ocean, soil and sunlight, opaque and transparent components. The orphan is guided by his voice to a translucent space where she can see the world as an interconnection between the past, the present and the future. The foreigner's voice claims that he went through time and space and was able to see through the earth and that he, a geologist by training, raped the Earth, then sought to save it, and then succumbed to a final indifference towards it. His telling of his own experiences through eternity seems at first to be justified by a desire to expose man's destruction of the earth. But in fact, it operates as a theorizing of social space which harks back to Pierre Bourdieu's idea that science and education condition the position of man as an agent (53-5). According to the sociologist, the social sphere consequently becomes dependent upon divisions and rivalries, upon the position of dominant v. dominated, orthodox v. heterodox - binaries that social agents acknowledge as legitimate and that they reproduce as self-evident. The foreigner's account of his personal history uncovers an evil world triggered by man's never-ending violence and greed:

I saw the knowledge I possessed had other uses. Colleagues of mine were being taken up by wealthy companies searching for oil and gas and minerals. There was a growing demand for these things in the more modern countries, and huge amounts of money to be made. [...] I decided I may as well get rich. I hired myself out to mining companies at first, surveying. I had an instinct about the earth, and an uncanny talent for uncovering its hidden riches. [...] I expanded into oilfields and power stations and refineries, too. It was the perfect time for such investments. Another world war was looming, and the demand for resources would soon be insatiable [...] It was intoxicating that wealth. I felt invulnerable. Powerful. Virtually immortal. (118-9, emphasis in the original)

The character insists that he has extensive knowledge about the manifestations of the earth and the ways in which man can possess natural riches, even temporarily so. But he considers he is neither a guardian angel nor a supernatural being; he insists that he is "nothing" compared to the orphan (87) whom he says is a wonder (88) in a godless world. The very setting, the psychiatric hospital situated on the verge of the main town which is itself dominated by an active volcano, accounts for a heterotopia enclosing the lives of patients who drift between the daily reality and imagination. The hospital clearly juxtaposes the many psychological spaces that the main characters inhabit outside social norms.

The integration of the foreigner in the psychiatric ward is soon followed by a series of bizarre murders throwing the lives of the patients and the island's inhabitants into a spiralling turmoil, bringing awe and terror, suggesting that the place is inhabited by evil forces and that the foreigner, despite his coma, is no stranger to the uncanny pheno- 
mena. Moreover, the orphan's personal development and incursions into the foreigner's many histories are marked by magical events which are linked emotionally and psychologically not only to her but also to four other patients from the psychiatric ward identified as "the duke, the witch, the archangel and the virgin" (17). The respective stories of the duke and the witch encapsulate elements from classic fairy tales but such elements are inverted in the course of time, the characters going from riches to rags, being doomed to madness and living unhappily ever after. Born in a long line of colonial property owners, and once destined to a wealthy and promising future, the duke lost his status and fortune after the departure of the colonial authorities, when a mob managed to take the upper hand on his family property. Once an innocent girl, the witch lost her sanity casting magic spells to overcome her own poverty and doom. The interaction of such peripheral characters and stories emphasize the orphan's own extraordinary ascent from her dull reality to the marvellous and uncanny reality of the earth - the axis of the multi-layered narratives. Thus, the main story encapsulates two conflicting perspectives, one based on a rational view of reality, and the other on the acceptance of the supernatural and apocalyptic tale as prosaic reality. As a result, the extraordinary exploration of consciousness, reality and madness, becomes the orphan's eye-opening journey into the elements: water, wind, rock - even outer space and the workings of the solar system. The main characters' experience suggests that transparency originates in the darkness of the earth, in the interplay between the obvious and the unsaid. Such a journey is marked by the orphan's constant wondering whether she is experiencing real events, bringing to the fore questions of viewpoint and reliability:

She turned a slow circle, her head tilted to the empty slopes. It was all so alien that she didn't feel afraid. Was she dreaming? Had she fallen over and hit her head? That could explain it. And yet she had never dreamt anything like this before. Her dreams were about the hospital, about places and people she knew, distorted perhaps, and bizarre, but still recognizable. There was nothing she recognised here. [...] Perhaps it was her madness, then. She knew what it was when people saw things that weren't there. The nurses called it hallucinating. But surely hallucinations weren't like this. Not so concrete. (35, emphasis in the original)

Fantasy expresses the reality of the orphan's inner world, making visible her secret interrogations, fears and doubts. The character's thoughts and interrogations suggest that the supernatural and natural are contiguous and interacting spaces, so that the unreal manifests itself as part of her reality. The unexpected alteration of reality is no longer displayed as questionable. Thus, while the reader may consider that the rational and irrational are mutually exclusive, their merging is not as disconcerting as one would expect because the supernatural is integrated within the norms of perception of the narrator and characters in the fictional world. The nameless orphan's biography gives a perfectly ordinary explanation for her mental retardation and for the foreigner's voice lodged inside her mind. She can see through the insanity of the patients, she can read through the weather with uncanny prescience, and even sense the volatile geology at work inside her island home's restive volcano (51-2). The story combines strategies of the orphan's invisibility from the perspective of the hospital staff and townspeople with the staging of the self and the visibility of otherness. The orphan, who is depicted as the innocent other, is ironically able to provide some transparency on the state of the world.

The character leads an isolated and strange existence with no experience of the world beyond the island, and she gradually becomes connected to the environment and 
the foreigner's past lives. She is endowed with the power to travel through time, to see through place and people. She is able to see through the surrounding natural elements and to express a view on the state of the many worlds she experiences through the mystical power of the foreigner's voice:

The vibrations - they were real! ... The ground shook ... She saw that a giant fist of grey smoke has appeared from nowhere and was rising into the sky ... She reached out and felt the earth. Sensations filled her head. Pressure... She could picture it down there almost as if the earth was transparent. (30)

The sense of space and connection with the natural elements is associated with the character's consciousness of being in the world. The eruption of the volcano marks the orphan's separation from her past life, and her newly acquired sense of existence. The centrality of the earth, and the way in which it animates human beings is somehow reminiscent of the romantic approach of German poet Novalis with the deification of Nature, the demand for the Absolute and the idea of spiritual birth or rebirth. In fact, Gaston Bachelard's comments on Novalis may well illustrate the orphan's many voyages through time and her inner sensations considering that she, like all characters, is tied up to the earth and that the latter animates the human heart and soul. The foreigner's accounts and the orphan's integration in his psychological meanderings through an opaque time and space provoke the orphan's

need to penetrate, to go to the interior of things, to the interior of beings; a need which is one attraction of the intuition of inner heat. Where the eye cannot go, where the hand does not enter, there where heat insinuates itself. This communion at the interior will [...] find its symbol in the descent in the depths of the mountain, into the grotto and the mine. It is there that the heat is diffused and equalized, that it becomes indistinct like the contour of a dream. (Psychoanalysis of Fire 40)

In fact, the orphan's participation in the foreigner's re-enacting of his past lives is supported by her curiosity and desire to enter other people's lives through the manifestations of a vibrating environment - the anthropomorphized landscape which seems to provide her with unknown sensations, sexual and spiritual ecstasy, and thus femininity.

Landscape is at the centre of the characters' personal story and imagination, encapsulating a prophetic truth which is perceived through the characters' respective madness. The story rests upon a never-ending negotiation between the "ordinary" and the "extraordinary," the "personal" and the "public," the "physical" and "metaphysical," "reality" and "illusion," (314-5) so that readers are encouraged to look beyond the surface of things. Fantastic elements design a sub-world which discloses the otherness of the world. The fairy-tale and fantastic effect is, in fact, a mode of concealment which gradually leads to the reality at the centre of the characters' respective emptiness. In the course of events, the foreigner seems to have lived as a wandering Jew in a forever changing world devoid of spirituality while the orphan appears to be drifting in a mental no-man's-land. The novel intertwines bizarre, magical and phantasmagorical elements with a rational view of the world, so that the extraordinary conveys truth and reality while the ordinary exposes the orphan's and the world's failure in perception:

She hung poised in space. Alone.

In reality, the orphan knew, she was asleep. In reality, she was still tied to the bed in the locked ward, the drugs stupefying her. In reality the foreigner was recuperating in the 
empty crematorium, and there was no way she could have travelled into space of her own. This was only a dream.

But she knew too that it was more than that. It was something that was going to happen. For real. Somehow she was seeing into the future. She was floating in the void, and had been placed as a spectator, safely out of the way, but with a perfect view. For here it came - the earth. [...] All those people, in the towns, in the hospital. What would they see if they looked to the sky? The sun would be on the horizon, but overhead would be a shining white portend of the end, terrifying. (293-4)

The orphan's incursions into the foreigner's personal history, and the history of the world, mark the collapsing of the psychic boundaries of self and other, life and death, reality and fantasy. The foreigner's spell on the patients and on the orphan stems from a transcendental power that binds reality to an imaginary world unleashed by natural (real) forces; a transcendental space where they can all become other (127).

The seeking of transcendence through the novel has been a strong element in Australian fiction ever since Patrick White suggested in The Tree of Man that God was in a "gob of spittle" (476). White's own use of landscape as the space of visionary revelations and truth, as a reaction against normative structures and colonial perceptions of space, still holds a central place in Australian writing. Indeed, McGahan's writing uses space as a central feature of the dramatized image of the environment and of the history of people, as a site of anxiety and the place where the characters simultaneously belong and do not belong. Thus, in the novel, the definition of space incorporates Gaston Bachelard's idea that space is affiliated with the question of when and how an observant (the fictional character and / or narrator) is situated in a given place, and how this place is related to the larger space of which it forms a constituent element. In the novel, McGahan stresses the link between space and identity formation, pointing out in the Bachelardian sense that "space contains compressed time," that one is in fact unable to relive duration, that one can only think of it in the line of an abstract time that is deprived of all thickness (Poetics of Space 8-9).

The orphan's thoughts suggest that reality relies on shifting perspectives so that the foreigner's past is rendered more plausible and real not when both he and she voyage back in time but when they come out from their respective limbos, since at that particular moment in time the present reality becomes unreal. In fact, the orphan gradually becomes a marvellous emblem of a world devoid of spirituality, humanity and wisdom, since she can see through the imaginative (and unreal) story of the foreigner when he explains that the outbursts of the volcano and the earthquakes reflect the physical violence that people inflict upon others or themselves: "She felt that a façade had been fractured. The volcano erupting, the duke's attack, the witch's self-inflicted injuries ... each of those occurrences had sent ripples of apprehension through the wards" (251).

The novel balances the logic of science with the imagination but above all, as McGahan argues, it uses the mythical or fairy-tale effects to address its central purpose which is the wonders of the earth:

Originally, I was trying to come up with a story that involved no human characters at all, instead using only the forces of nature interacting in a kind of wordless planetary drama. I couldn't make that idea work, but then the orphan and the foreigner emerged. The orphan - a girl freakishly in tune with the planet and its processes, but so out of tune with humanity that she can't talk or even remember her own name. And the foreigner - a man utterly out of tune with the planet and doomed time and time again to die in natu- 
ral disasters, and yet whose own outrage always brings him back to life. From there, all the weird and interesting stuff about Earth that I originally wanted to explore could be played out in the relationship between these two. (Case)

Some critics claim that McGahan's apocalyptic vision takes James Lovelock's Gaia hypothesis to recast it as an ecological parable about global warming, which McGahan denies in his interview with Jo Case. Instead, I would argue that, rather than simply using Lovelock's suggestion that all organisms and their inorganic surroundings on earth are closely integrated to form a single and self-regulating complex system, maintaining the conditions of life on the planet, Wonders of a Godless World suggests that natural history and human history are inextricably bound together. The displacement of the two main characters back into the past not only assesses that climate change altered human history, but also that human beings are geological agents living in a world that historian Dipesh Chakrabarty would define as "the age of the anthropocene" (197-222) - an age in which man has become a dominant force shaping the planet to such an imaginative extent that the planet strikes back and imposes its own destructive laws on man's life. McGahan's novel is composed of divergent but contiguous stories that verge on fantasy to provide some clarity on the state of the world and reality. The novelist's interest in the surreal interrogates realism but is also related to a cultural ecology advocating a vital interrelatedness between culture and nature. The foreigner's statements naturally suggest that everything in human history is rooted in the earth, and that urban development is devastating to man's cultural legacy and history.

The exploitation of natural resources in mining and oil-drilling schemes defines human greed, vanity and insanity, as the expression of "cold reality" (118), a reality which extends to the re-enacting and recounting of the colonizing practices of the Western world including land deprivation, the ignorance of indigenous identity and beliefs, economic expansion; practices that may recall the colonization of Australia (121). Yet, the discourse about the land and the primacy of natural elements should be interpreted as a plea for the environment and for the individual's need to come to terms with otherness, suggesting that even though they can be anywhere the characters are indeed trapped in a global consciousness.

The encroaching of fantasy and reality opens up a vista onto current global environmental issues, natural disasters that occurred in reality and extend to the imaginary world of the orphan and the foreigner, as McGahan himself asserts in an interview with Peter Mares:

Yes, they're all notifiable events that you can check up. But it was important to root all the fabulous stuff [...] back into real science, because otherwise if they're just floating around out there where they could do anything and there's [sic] no rules that apply to them, then that gets pretty boring fairly fast. You've got to have some reality around fantasy otherwise it's just made-up nonsense in the end. So for all the weird stuff that goes on, it's always tied back to reality, and they always come back to reality.

The characters' experience of the world swings between extremes, unification and fragmentation, peace and turbulence. It is marked by their exposure to global warming, pollution, natural catastrophes - modern plagues and processes by which the wrath of the earth expresses itself and impacts on people's lives. The foreigner insists that the earth negates the Self and that it is the Tellus Mater that delineates the history of men and evolution of the world; that the earth is, in fact, the topography of intimate being: 
Looking down I saw beauty, yes, but not the beauty of an eggshell jewel - I saw the beanty of an immensely powerful beast. I saw the hard carved faces of the continents and the inexorable currents of the oceans flowing. I felt the atmosphere humming with electricity, and the inside of the planet bursting with suppressed heat. I sensed what a savage thing the world really is - strong, hot, and driven by systems so vast that they dwarf mankind and all his works to nullity. (237, italics in the original)

Like the psychiatric hospital, the outside is defined as a heterotopic entity creating a space of illusion that constructs otherness. The foreigner and the orphan respectively embrace the earth as a metaphor for the duality and contradictions of the world, but also as a physical representation of a utopian world where they can exist. Rather than implying something unreal, illusion prompts the decentring of reality, and the persona constructing various worlds and various meanings so that the reader is able to perceive, like the orphan, that what lies beyond the foreigner's history is a natural and supernatural explanation of the events: "Everything had been intertwined. All his tales about his many lives and deaths, all his stories about how the world worked..." (312).

The foreigner, who is depicted as the angel of destruction (289), acts as an evil destroyer of the witch's, the duke's and the virgin's life, being able to control their respective fates. He is also the author of the cautionary tale allowing the orphan to understand all the mysteries which have been hidden from her view. Yet, he is unable to mastermind the orphan's evolution and her subsequent escape from his imaginative world and space. The orphan evolves from being the symbolic unwanted, unloved and needy character to a strong-willed figure challenging the foreigner, even though she cannot entirely escape from the strict dictates of his tale:

The foreigner's attack broke anew, a mad hammering at her mind. And the blows told. A certain numbness was creeping over her, a dislocation between thought and action. She was weakening. But she made herself move forward into the tube. It was black in there, yet her eyes could see. She carried the foreigner inwards for a distance, and then set him down on the rocky floor. Fifty paces behind her was the opening, and fifty paces ahead the tube ended in a blank stone wall. (321)

The orphan attempts to fight against the central presence of the comatose foreigner as soon as she considers that he is an agent of evil. As the story unfolds, she gradually becomes a "counter-narrator" to the foreigner who initially seemed to be the legitimate story-teller, pondering on his statements, questioning the reality of his history and giving the reader a transparent access to his obscure nature. The story subverts the idea of awareness via the orphan's imagination and madness. Characters are "trapped in a shadowy limbo" (208) and the foreigner's supernatural powers and discourse can only be expressed through the orphan's imagination: "I am free to roam with my mind, but to affect reality, to shift flesh and bone, that's not something I can do" (245).

The foreigner expresses anger and confusion at the way he has been "creating illusions" (209) through his many lives (which he sees as a gift of eternity) but he also insists that reality and the sense of otherness or being are conditioned by dreams:

\footnotetext{
I did not want to wake from those dreams. It was no help to tell myself that the ocean was less than onethousandth of the world's mass. It was still vaster than anything I had encountered before, a wilderness beyond any other. And the pulse of the currents was endlessly bypnotic. Like blood in arteries, like a mother's heartbeat to a child in the womb. I had only to close my eyes at night and I was entranced. (207, italics in the original)
}

The foreigner's direct addresses to the orphan operate through the power of the orphan's imagination; his voice interacts with the orphan's as well as with the voice of the 
narrator. Indeed, throughout the novel the opening-up of a narratorial hybrid space, in the Bakhtinian sense of dialogised heteroglossia, rests upon the idea of transparency. Such an idea stems from the alternating of the girl's stream of consciousness, in normal script, with the external commanding voice of the foreigner, in italics. Thus, the dual narrative makes it difficult to conceive the "real" as a single world. McGahan's dual narrative associates what is not visible in the real world with the staging of the self in imagination so that events are open to interpretations and never restricted in their meaning:
Shoving the chair through the fence, the orphan began the long climb. She had expected protests from him. She had expected anger, and some kind of struggle, a grappling of her mind, an attempt to turn her from her course. [...] His body flopped against the seat, passive, a dead weight. And when finally he did break his silence, it was merely to ask a question. Quietly. Thoughtfully.
Orphan, have you ever wondered if any of this is real?
Real? What did he mean - real?
Well, you live in a hospital for the insane, after all. And you've always imagined strange things about yourself. That you can predict the weather, for instance, and that you can overbear people's thoughts. So maybe... Ha. Was she imagining the volcano erupting? I don't mean the volcano. I mean you and me. All we've done together. Are you sure any of it actually happened? (308-9, italics in original)

In this passage, fantasy dovetails with the theme of mental instability and the interrogation of real experience and imagined reality so that the orphan - and the implied reader - cannot answer the foreigner's direct question. The text thus remains purely fantastic.

The orphan suspects the foreigner of entering into malicious communion with the patients, awakening their dormant madness and appropriating their inner space. She also wonders about his evil nature and lack of morality, seeing in nature no purpose or intent and seeing the earth as nothing but a collection of complicated systems on which life or men had no special claim (181). She naturally becomes an allegorical subject standing for the human soul and opposing the destructive design of the foreigner. Her consciousness develops as a site of difference and anti-social possibility, she becomes the embodiment of mimesis and alterity so that, contrary to the foreigner who in his fifth and final life is "imprisoned within the four walls of the globe" (231), she is able to escape and to free herself in a symbolic moment when she recovers her own memory and voice, crying out to the outside reality:

And something was rising in her throat, pushing against vocal cords that had never formed a word, something incredible. The rock filled the night sky. She could still step back and let it miss her, she knew. She could still withdraw her choice and return to what she had been. There was still time. Why, everlasting life, if she wanted. But the thing in her throat was bursting. "Ha!" cried the orphan, out loud. And stepped forward. (327)

The orphan's interjection openly marks her becoming a voice of conscience, her stepping back into reality. At that very moment the character becomes the object of a narrative that encodes and preserves the world's otherness, the otherness of the other and the otherness of the self to oneself. At the end of the story, the character magically recovers her voice and identity after she has undergone a series of ordeals, one of which is to record every single element in the infinite multiplicity of the foreigner's lives as a means of existence. She virtually loses her initial sense of nothingness to achieve a state of being and a potential future through the transgression of the imaginary world of the foreigner - a transgression that establishes a relation between language and reality and that again interrogates the nature of consciousness and reality. Through such a vivid 
scene and tangible reality, what was extraordinary then appears more plausible although the explanation for such a recovery still appears strange and illogical.

McGahan's novel propose an idiosyncratic history in a modern society through the inclusion of fantastic elements. Wonders of a Godless World suggests that history is a prophecy and that once we, readers, accept the fait accompli and enter the fantastic world of the main protagonists, the story can unravel with logical (im)precision. We, readers, are made to understand that the imagination is encapsulated in reality and that it is through the transparency of the imagination that reality can best be grasped.

Salhia Ben-Messahel

Charles-de-Gaulle University (Lille 3)

\section{Works Cited}

Bachelard, Gaston. The Psychoanalysis of Fire. Trans. Alan C. M. Ross. London: Routledge, 1964.

—. The Poetics of Space. Trans. Maria Jolas. Boston: Beacon P Books, 1994.

Bourdieu, Pierre. Raisons pratiques. Sur la théorie de l'action. Paris: Seuil, 1994.

BAKHTIN, Mikhail. "Discourse in The Novel." The Dialogic Imagination: Four Essays. Trans. Michael Holquist and Caryl Emerson. Austin: U of Texas P, 1981. 259-422.

Case, Jo. "An Interview with Andrew McGahan." Victoria Readings. 1 October 2009.<http://www. readings.com.au/interview/andrew-mcgahan>.

ChakrabarTy, Dipesh. "The Climate of History: Four Theses." Critical Inquiry 35.2 (2009): 197-222.

Holt-Jensen, Arild. Geography, History \& Concepts. London: Sage, 1999.

Foucault, Michel. "Dits et écrits 1984, Des espaces autres (conférence au Cercle d'études architecturales, 14 mars 1967)." Architecture, Mouvement, Continuité 5 (octobre 1984): 46-9.

Lovelock, James. The Ages of Gaia: A Biography of Our Living Earth. New York: Norton, 1995.

Mares, Peter. Interview with Andrew McGahan. The Book Show. ABC Radio National. 19/10/2009.

McGahan, Andrew. Praise. Sydney: Allen \& Unwin, 1992.

—. The White Earth. Sydney: Allen \& Unwin, 2004.

—. Underground. Sydney: Allen \& Unwin, 2006.

-Wonders of a Godless World. 2009. London: Harper \& Collins, 2010.

White, Patrick. The Tree of Man. London: Penguin, 1984. 